http://ejournal.iainu-kebumen.ac.id/index.php/A r-rihlah/index

\title{
ISLAM DALAM MEMANDANG BUDAYA SELAMETAN BUMI
}

( STUDI KASUS DI DESA BALOREJO, BONOROWO, KEBUMEN)

\author{
Bahrun Ali Murtopo \\ Dosen Institut Agama Islam Nahdlatul Ulama Kebumen \\ Linda Suci Dwi P \\ Mahasiswa IAINU Kebumen \\ Bahrunalimurtopo@gmail.com \\ lindasucidwi10@gmail.com
}

\begin{abstract}
Abstrak
Tradisi sedekah bumi legenanan merupakan sebuah tradisi yang dimiliki oleh masyarakat hingga sekarang ini masih mempertahankan dan masih rutin melaksanakan tradisi sedekah bumi legenanan untuk setiap tahunnya. Tujuan penelitian: (1) Mengetahui prosesi pelaksanaan tradisi sedekah bumi legenanan di (2) Mengetahui makna simbolik yang terdapat dalam pelaksanaan tradisi sedekah bumi legenanan. Hasil penelitian ini menunjukkan bahwa: (1) Tradisi sedekah bumi legenanan dilaksanakan setiap setahun Desa Balorejo. Tradisi tersebut menunjukkan akar dari tradisi agraris dan tetap dilestarikan oleh masyarakat setempat. Makna simbolik yang terdapat dalam pelaksanaan tradisi sedekah bumi legenanan yaitu sebagai bentuk rasa bersyukur kepada Allah swt dan memohon kepada Allah swt agar diberi keselamatan, kesehatan, keberkahan, rejeki yang melimpah, bumi yang dipijak agar tetap utuh tidak runtuh, tidak ada bencana apapun yang melanda Desa Balorejo dan masyarakat Desa Balorejo menjadi masyarakat yang makmur sejahtera. Makna simbolik yang mengandung nilai-nilai budaya ini oleh masyarakat dijadikan sebagai pedoman hidup yang sudah mengakar dalam masyarakat.
\end{abstract}

Kata Kunci: Islam Dalam Memandang Budaya Selametan Bumi 


\section{A. Pendahuluan}

Indonesia memiliki masyarakat yang beragam. Keragaman dalam berbagai relasi kini telah menjadi tanda bagi mayoritas masyarakat besar hampir di seluruh kawasan dunia. Kekayaan akan keanekaragaman agama, etnik, dan kebudayaan ibarat pisau bermata dua. Di satu sisi kekayaan ini merupakan khazanah yang patut dipelihara dan memberikan nuansa dan dinamika bagi bangsa dan dapat pula merupakan titik pangkal perselisihan. Keragaman bahasa dan agama akan memperbesar keragaman, apalagi jika bertemu dengan keragaman gaya hidup yang memperlihatkan bentuk-bentuk budaya tradisional. ${ }^{1}$

Budaya tradisional atau disebut sebagai budaya lokal adalah istilah yang biasanya digunakan untuk membedakan suatu budaya dari budaya nasional (Indonesia) dan budaya global. Budaya lokal adalah budaya yang dimiliki oleh masyarakat yang menempati lokalitas atau daerah tertentu yang berbeda dari budaya yang dimiliki oleh masyarakat yang berada di tempat yang lain. Permendagri Nomor 39 Tahun 2007 pasal 1 mendefinisikan budaya daerah sebagai "suatu sistem nilai yang dianut oleh komunitas/kelompok masyarakat tertentu di daerah, yang diyakini akan dapat memenuhi harapan-harapan warga masyarakatnya dan di dalamnya terdapat nilai-nilai, sikap tata cara masyarakat yang diyakini dapat memenuhi kehidupan warga masyarakatnya". ${ }^{2}$

Budaya tradisional yang berkembang di kalangan masyarakat sangatlah beragam. Keragaman ini bukanlah sebagai suatu problem yang akan memecah belah masyarakat, tetapi sebagai alat pemersatu bangsa. Hal ini bertujuan untuk menyatukan dan saling mengenalkan budaya masing-masing daerah. Untuk mengantisipasi hal-hal yang demikian, maka diperlukan sikap multikulturalisme untuk saling menghargai antar sesama.

\footnotetext{
1 Zakiyuddin Baidhawy, Pendidikan Agama Berwawasan Multikultural, (Jakarta: Erlangga, 2005), hal., 21-25.

2 Agung Setiyawan, Jurnal Budaya Lokal dalam Perspektif Agama: Legitimasi Hukum Adat ('Urf) dalam Islam, (Yogyakarta: Universitas Muhammadiyah Yogyakarta), hal., 6
} 
Selain itu, relasi di lingkungan masyarakat ini perlu untuk menghadirkan sebuah agama. Agama yang benar itu bagaikan lampu yang menerangi umat untuk berjalan menuju ke arah kemajuan. Mengamalkan ajaran-ajaran agama adalah petunjuk jalan untuk seluruh umat manusia. Agama adalah ciptaan Allah, maka akan terasa janggal bagi akal sehat, jika sekiranya Allah memerintahkan kepada hamba-Nya untuk berbuat kejahatan yang dapat menyebabkan mereka terhambat untuk mencapai kehidupan yang layak dan diridhai-Nya. Tidak ada sesuatu pun yang dapat membahagiakan manusia, kecuali mengamalkan agama dan tidak ada sesuatu pun yang dapat mencelakakan mereka kecuali mengabaikan agama atau berpegang dengan bagian luar (kulit) agama dan meninggalkan inti ajarannya.

Meluasnya Islam ke seluruh dunia tentu juga melintas aneka ragam budaya lokal. Islam menjadi tidak satu, tetapi muncul dengan wajah yang berbeda-beda. Hal ini tidak menjadi masalah asalkan substansinya tidak bergeser. Artinya, rukun iman dan rukun Islam adalah sesuatu yang tidak bisa di tawar lagi. Bentuk masjid kita tidak harus seperti masjid-masjid di Arab. Atribut-atribut yang kita kenakan tidak harus seperti atribut-atribut yang dikenakan bangsa Arab. Festival-festival tradisional yang kita miliki dapat diselenggarakan dengan menggunakan acuan Islam sehingga terjadi perpaduan yang cantik antara warna Arab dan warna lokal. Lihat saja, misalnya, perayaan Sekaten di Yogyakarta, Festival Wali Sangan, atau perayaan 1 Muharram di banyak tempat. ${ }^{3}$

Dialog kreatif antara Islam dan budaya lokal tidaklah berarti mengorbankan Islam, dan menempatkan Islam kultural sebagai hasil dari dialog tersebut, sebagai jenis Islam yang rendahan dan tidak bersesuaian dengan Islam yang murni, yang ada dan berkembang di Jazirah Arab, tapi Islam kultural harus dilihat sebagai bentuk varian Islam yang sudah berdialektika dengan realitas di mana Islam berada dan berkembang. Menjadi Islam, tidak harus menjadi Arab. Islam memang lahir di Arab, tetapi tidak hanya untuk bangsa Arab. Proyek Arabisme merupakan proyek politik yang berkedok purifikasi Islam yang berusaha menjadikan Islam sebagai sesuatu yang tunggal dan seragam

\footnotetext{
${ }^{3}$ Agung Setiyawan, Ibid., hal., 9.
} 
(Abdurrahman Wahid, 2009: 19-20). Dalam pemahaman mereka, Islam kaffah adalah Islam yang ada dan berkembang di Arab, sehingga seluruh komunitas Islam harus mengikuti pola keberagamaan dan keyakinan yang mereka anut dan praktikkan. Tradisi dan adat-istiadat setempat bagi mereka merupakan bid'ah (sesat), yang dapat mencemarkan ajaran Islam yang sesungguhnya. ${ }^{4}$

Dalam Islam, antara agama dan budaya lokal seringkali mengambil hubungan yang tumpang tindih. Agama dengan watak misionarismenya selalu hendak hadir meng-agamakan budaya yang dipelihara masyarakat. Dengan kata lain, agama bukan untuk menyuburkan budaya yang telah ada, melainkan sebaliknya berusaha untuk menghilangkannya. Di berbagai wilayah Indonesia, setiap kebudayaan memiliki kepercayaan lokal masing-masing. Termasuk di beberapa wilayah Indonesia, ada agama lain yang berusaha untuk menghilangkan budaya yang telah lama berkembang, termasuk di dalamnya ada kepercayaan lokal. $^{5}$

Di daerah Kebumen, khusunya Desa Balorejo, Kecamatan Bonorowo pergumulan agama dan budaya lokal juga masih berlangsung dan mendarah daging. Adapun budaya lokal yang berlangsung yaitu selametan bumi, wetonan, meling, among-among, dan sebagainya. Tradisi ini, tidak hanya berkembang di Desa Balorejo, tetapi juga berkembang di berbagai wilayah sekitar Kebumen.

Sedekah bumi atau yang lebih akrab disapa sebagai selametan bumi merupakan salah satu bentuk ritual tradisional masyarakat di Desa Balorejo secara turun-menurun dari nenek moyang terdahulu.

\section{B. Pembahasan dan Hasil}

\footnotetext{
${ }^{4}$ Sumper Mulia Harahap, Jurnal Islam dan Budaya Lokal, (Padang: IAIN Padang Sidimpuan, 2015), hal., 6.

${ }^{5}$ Oom Komaruddin Maskar, Jurnal tentang Pergumulan Agama dan Budaya Lokal, (Indramayu: STAI Sayid Sabiq Indramayu, 2011), hal., 3.
} 


\section{a. Islam dan Selametan Bumi}

Kata Selametan berasal dari Bahasa Arab yaitu salamah yang artinya keselamatan, kesehatan atau perlindungan. Bagi masyarakat Jawa, selametan memiliki arti lain yaitu memberi mereka kebersamaan di antara mereka, yang akan menjauhkan mereka dari perpecahan atau pemisahan. ${ }^{6}$

Di kalangan masyarakat, istilah selametan sering disebut dengan istilah kenduri ataupun sedekah. Menurut Dr.Purwadi sebagaimana dikutip oleh Khikmah Umul Khabibah bahwa upacara selametan adalah upacara sedekah makanan dan doa bersama untuk memohon keselamatan dan ketentraman untuk ahli keluarga yang menyelenggarakannya. Istilah selametan sering diasosiakan dengan istilah sedekah dan kenduri.

Upacara selametan merupakan kegiatan batiniyah yang bertujuan untuk mendapat ridha Tuhan. Kegiatan ini juga menjadi tradisi yang melekat di sebagaian besar masyarakat Jawa. Sebagian masyarakat yang berkeyakinan bahwa selametan merupakan syarat spiritual wajib yang apabila dilanggar akan mendapatkan ketidakberkahan atau kecelakaan. Upacara seperti ini sudah cukup terkenal di kalangan masyarakat Jawa.

Islam sebagai agama memandang bahwa selametan bumi merupakan suatu budaya lokal yang telah melekat pada kehidupan masyarakat. Budaya lokal (juga sering disebut budaya daerah) merupakan istilah yang biasanya digunakan untuk membedakan suatu budaya dari budaya nasional (Indonesia) dan budaya global. Budaya lokal adalah budaya yang dimiliki oleh masyarakat yang menempati lokalitas atau daerah tertentu yang berbeda dari budaya yang dimiliki oleh masyarakat yang berada di tempat yang lain. Permendagri Nomor 39 Tahun 2007 pasal 1 mendefinisikan budaya daerah sebagai "suatu sistem nilai yang dianut oleh

\footnotetext{
${ }^{6}$ Khikmah Umul Khabibah, Skripsi tentang Nilai-Nilai Pendidikan Islam dalam Adat kebudayaan Selamatan Bumi di Desa Sidobunder Kecamatan Puring Kabupaten Kebumen, 2015 hal., 16.
} 
http://ejournal.iainu-kebumen.ac.id/index.php/A r-rihlah/index

komunitas/kelompok masyarakat tertentu di daerah, yang diyakini akan dapat memenuhi harapan-harapan warga masyarakatnya dan di dalamnya terdapat nilai-nilai, sikap tata cara masyarakat yang diyakini dapat memenuhi kehidupan warga masyarakatnya". ${ }^{7}$

Dengan dikaitkannya islam dan budaya lokal, diharapkan Islam sebagai agama dapat memberikan arahan positif dan mendukung budaya agar memiliki nilai positif dan berguna bagi masyarakat yang menjalankannya. Sehingga, budaya lokal bukanlah mitos belaka dan terkesan merupakan sesuatu yang sia-sia. Terlepas dari hal tersebut, agama dan budaya memiliki fungsi yang serupa, yaitu untuk memanusiakan manusia dan membangun masyarakat yang beradab dan berperikemanusiaan.

\section{b. Konstruk Budaya}

Menelusuri tentang kehidupan di Desa Balorejo, terdapat sebuah budaya lokal yang telah mendarah daging di kalangan masyarakat. Budaya tersebut adalah selametan bumi. Budaya ini merupakan budaya tahunan yang diadakan setiap satu tahun sekali, khususnya di bulan Sura. Sebagai salah satu warisan nenek-moyang yang turun-menurun dilakukan hingga saat ini, selametan bumi sudah menjadi budaya yang sangat sakral. Mengapa demikian? Pasalnya, budaya yang sudah menjamur di kalangan umat Islam ini, sudah memunculkan berbagai akibat buruk jika tidak melaksanakannya di tiap tahunnya.

Hal ini sudah dirasakan oleh masyarakat di tetangga sebelah. Saat itu, salah satu pejabat desanya menyatakan bahwa budaya selametan bumi yang dilakukan di desanya merupakan salah satu bentuk kemusyrikan. Atas dasar demikian, pejabat ini melarang warganya melakukan budaya lokal ini dan ia menyatakan bahwa ia berani menanggung semua bebannya jika terjadi apapun pada dirinya karena tidak menjalankan kebiasaan budaya ini. Beberapa hari kemudan, pejabat tersebut meninggal dunia. Dan masyarakat menganggap bahwa itu merupakan ulahnya sendiri karena tidak mau

\footnotetext{
${ }^{7}$ Agung Setiyawan, Op.Cit., hal., 6.
} 
menjalankan budaya lokal ini. Semenjak kejadian ini, masyarakat di desa ini menjalankan budaya ini.

Selain kejadian di atas, di tetangga sebelah juga mengalami hal yang demikian. Saat itu, masyarakat melanggar aturan yang ditetapkan nenek moyangnya. Bahwa dalam aturan tersebut dikatakan bahwa untuk penyembelihan kambing selametan bumi harus kambing yang berjenis kelamin laki-laki. Namun karena faktor apa (peneltii tidak mengetahuinya), mereka menggunakan kambing berjenis kelamin perempuan. Dan akibatnya, masyarakat perempuan di kompleks tersebut mengalami gangguan kejiwaan (gila). ${ }^{8}$

Lain halnya dengan selametan bumi yang dilaksanakan oleh masyarakat Desa Balorejo. Budaya lokal ini selalu dilakukan oleh masyarakat di setiap tahunnya. Budaya ini dilakukan di setiap bulan Sura. Dan untuk menentukan harinya, ditentukan berdasarkan weton kelahiran Kepala Desanya. Adapun rangkaian acara selametan bumi ini dimulai dari penyembelihan hewan kambing jantan yang dilakukan di rumah kediaman Pak bayan.

Dana untuk penyembelihan kambing ini berasal dari masyarakat dan nantinya akan dibagikan kepada masyarakat pula dengan kondisi yang sudah matang. Sehingga, masyarakat dimudahkan untuk langsung menyantap masakan ini. Iuran ini memang tidak diwajibkan, tapi sangat dianjurkan bagi masyarakat walaupun tidak membayar sesuai iuran yang ditetapkan. Tentunya iuran yang berbeda juga akan mendapatkan bagian yang berbeda pula. Penyembelihan kambing ini dilakukan di setiap dusun. Dengan demikian, satu desa menyembelih kambing sebanyak 4 ekor.

Setelah kegiatan penyembelihan ini yang dilakukan secara gotong royong, kemudian dilanjutkan acara selanjutnya yaitu kepungan untuk selametan desa. Aturannya yaitu setiap masyarakat yang datang pada acara kepungan ini diharuskan membawa nasi, sayur, dan lauk, serta daun pisang,

\footnotetext{
${ }^{8}$ Wawancara dengan Nur Hadi pada tanggal 25 Juni 2018, pukul 09.45 WIB
} 
yang diletakkan dalam sebuah rinjing atau baskom yang berukuran cukup besar. Makanan ini nantinya akan dicampur jadi satu dengan makanan masakan orang lain, sehingga diharapkan tiap orang pulang ke rumah membawa masakan orang lain. Dan masakan sendiri dibawa pula oleh orang lain. Sedangkan daun pisang yang dibawa, digunakan untuk digelar untuk mencampuradukkan sayur yang dibawa.

Kegiatan ini merupakan kegiatan yang dilakukan oleh kaum laki-laki (kaum bapak). Namun, ada beberapa wanita yang ikut serta dalam kegiatan ini. Begitu besar antusias warga dalam kegiatan selamatan bumi ini. Budaya kepungan ini dilakukan setelah melaksanakan shalat dhuhur (sekitar pukul 13.00 WIB). Adapun rangkaian acaranya dipimpin oleh bapak kaum. Bapak kaum membuka acara dan memimpinnya dengan melakukan kegiatan tahlil secara bersama-sama. Setelah lantunan tahlil ini, kaum bapak disuguhkan dengan makanan ringan dan minumnya dan makanan kenduran sudah siap untuk dibawa kembali ke rumah masing-masing.

Satu hal yang perlu diingat oleh para pembaca, bahwa budaya kenduran atau kepungan ini bukanlah suatu hal yang diwajibkan. Tetapi merupakan suatu hal yang sangat dianjurkan. Namun, apabila ada masyarakat yang tidak memiliki kondisi ekonomi yang cukup baik, mereka tidak diwajibkan mengikuti kegiatan tersebut. Sebaliknya, mereka malah mendapatkan berkat atau makanan dari kepungan selametan bumi tersebut.

\section{c. Nilai-Nilai yang Terkandung dalam Budaya Selametan Bumi}

Pada proses pelaksanaan budaya selametan bumi di Desa Balorejo mengandung banyak sekali hal-hal yang positif, seperti sikap gotong-royong. Sehingga adat kebudayaan ini perlu dijaga serta dilestarikan terutama kepada generasi selanjutnya. 
Secara umum, nilai budaya orang Indonesia mengandung empat konsep. Pertama, manusia tidak hidup sendiri di dunia ini, tetapi dikelilingi oleh komunitasnya, masyarakatnya, dan alam semesta di sekitarnya. Kedua, dalam aspek kehidupannya manusia memiliki sifat ketergantungan pada sesamanya, terdorong karena jiwa sama rata, sama rasa. Ketiga, karena sikap demikian, maka seseorang berusaha untuk memelihara hubungan baik dengan sesamanya, terdorong oleh jiwa sama rata, sama rasa. Keempat, selalu berusaha untuk sedapat mungkin conform, berbuat sama dan bersama dengan sesamanya dalam komunitas, terdorong oleh jiwa sama tinggi, sama rendah. Keempat konsep ini merupakan sebuah konsep yang diharapkan dan diinginkan oleh masyarakat Balorejo pada umumnya.

Apabila hal ini dikaitkan dengan budaya selametan bumi di Desa Balorejo, maka budaya ini mengandung beberapa nilai. Diantaranya yaitu sebagai berikut.

a. Nilai religious, yaitu melalui kegiatan tahlil, masyarakat akan merasakan tenangnya hati dan semakin dekat dengan Allah Swt

b. Nilai sosial, yaitu akan memupuk jiwa gotong royong melalui kegiatan penyembelihan hewan kambing.

c. Nilai kemanusiaan, yaitu menumbuhkan dan memupuk jiwa sama rata dan sama rasa melalui kegiatan menyamaratakan dan mencampuradukan makanan kepungan yang dibawa oleh masyarakat.

Terlepas dari hal tersebut, budaya selametan bumi memiliki maksud agar bumi yang kita tempati ini mendapatkan keselamatan dan selalu menebar keberkahan kepada para penghuninya, dan masyarakat yang menempatinya selalu diberikan kesehatan dan dihindarkan dari segala bencana.

\section{Simpulan}


Islam sebagai agama tidak memerintahkan kepada pemeluknya untuk melaksanakan budaya selametan bumi ini. Tidak ada satu nash-pun yang menjelaskan tentang budaya tersebut. Karena istilah selametan dapat disejajarkan dengan istilah sedekah, maka ada beberapa nash Al Quran maupun Hadis yang menjelaskan tentang anjuran untuk bersedekah. Atas dasar inilah, dapat disimpulkan bahwa agama memiliki posisi yang sangat penting dalam kehidupan bermasyarakat. Agama dapat berfungsi sebagai pelurus, pembenar, dan pelengkap terhadap budaya masyarakat yang tidak sesuai dengan ajaran Islam. Sehingga tidak akan muncul berbagai mitos yang bersifat syirik.

\section{Daftar Pustaka}

Zakiyuddin Baidhawy. 2005. Pendidikan Agama Berwawasan Multikultural. Jakarta: Erlangga

Agung Setiyawan. Jurnal Budaya Lokal dalam Perspektif Agama: Legitimasi Hukum Adat ('Urf) dalam Islam. Yogyakarta: Universitas Muhammadiyah Yogyakarta

Sumper Mulia Harahap. 2015. Jurnal Islam dan Budaya Lokal. Padang: IAIN Padang Sidimpuan

Oom Komaruddin Maskar. 2011. Jurnal tentang Pergumulan Agama dan Budaya Lokal. Indramayu: STAI Sayid Sabiq Indramayu

Khikmah Umul Khabibah. 2015. Skripsi tentang Nilai-Nilai Pendidikan Islam dalam Adat kebudayaan Selamatan Bumi di Desa Sidobunder Kecamatan Puring Kabupaten Kebumen. IAINU Kebumen.

Wawancara dengan Nurhadi pada tanggal 25 Juni 2018, pukul 09.45 WIB 